\title{
Effects on the nervous system among welders exposed to aluminium and manganese
}

Bengt Sjögren, Anders Iregren, Wolfgang Frech, Maud Hagman, Lotta Johansson, Maria Tesarz, Arne Wennberg

\begin{abstract}
Objectives-The purpose was to study the effects on the nervous system in welders exposed to aluminium and manganese.

Methods-The investigation included questionnaires on symptoms, psychological methods (simple reaction time, finger tapping speed and endurance, digit span, vocabulary, tracking, symbol digit, cylinders, olfactory threshold, Luria-Nebraska motor scale), neurophysiological methods (electroencephalography, event related auditory evoked potential (P-300), brainstem auditory evoked potential, and diadochokinesometry) and assessments of blood and urine concentrations of metals (aluminium, lead, and manganese).

Results-The welders exposed to aluminium $(n=38)$ reported more symptoms from the central nervous system than the control group $(n=39)$. They also had a decreased motor function in five tests. The effect was dose related in two of these five tests. The median exposure of aluminium welders was 7065 hours and they had about seven times higher concentrations of aluminium in urine than the controls. The welders exposed to manganese $(n=12)$ had a decreased motor function in five tests. An increased latency of event related auditory evoked potential was also found in this group. The median manganese exposure was 270 hours. These welders did not have higher concentrations of manganese in blood than the controls.
\end{abstract}

Conclusions-The neurotoxic effects found in the groups of welders exposed to aluminium and manganese are probably caused by the aluminium and manganese exposure, respectively. These effects indicate a need for improvements in the work environments of these welders.

(Occup Environ Med 1996;53:32-40)

Keywords: aluminium; manganese; welding

During the 1930s and 1940s, exposure to aluminium powder caused pulmonary fibrosis and aluminosis. ${ }^{1}$ This disease disappeared when the working environment improved. Interest in this metal was renewed during the 1970s when it was found that patients on dialysis around the world developed severe brain damage. ${ }^{23}$ The disease typically had an insidious onset. Family members noted initially very subtle personality changes. The finding that most commonly led to the diagnosis of aluminium toxicity was speech disturbance. The speech disorder was characterised by a stuttering or stammering of speech, with hesitancy and at times total inability to speak. As the disease progressed the speech disturbances became more severe and eventually the patient became completely mute. ${ }^{4}$ Twitchings, myoclonic jerks, motor apraxia, and seizures occurred in about $75 \%$ of the cases. Today aluminium is firmly established as a neurotoxin in humans. ${ }^{4}$ The patients on dialysis had been exposed to aluminium from two sources. One route was through the drugs that contained aluminium, which were taken orally and used to lower the phosphate concentrations in blood. The other source was the water used for the dialysate. These patients with insufficient kidney function were particularly sensitive to aluminium exposure, as this metal is excreted through the urine.

Difficulty with speech was also an important symptom in one worker exposed to aluminium powder for 13 years. ${ }^{5} \mathrm{He}$ became forgetful, and also had attacks of clonic jerking of the left leg and later also the left arm, even though he was conscious. Motor disturbances and signs of dementia have recently been confirmed in a patient more than 40 years after aluminosis was diagnosed in $1946 . .^{6}$

Several investigations have surveyed the exposure to aluminium in Swedish industries. The highest blood and urine concentrations were found in welders exposed to aluminium and in flake powder producers. ${ }^{7-9}$ In welders exposed to aluminium long term high concentrations have been found in the skeleton. ${ }^{10}$

Symptoms from the central nervous system have been most prevalent in welders with long term exposure to aluminium. ${ }^{11}$

The neurotoxic effect of manganese has been known for a long time. After heavy exposure, two types of effects have been found. After a short period of time psychiatric symptoms dominate, manganese madness, with hallucinations, emotional lability, and compulsive and aberrant behaviour. Later, neurological symptoms, with muscular weakness, impaired speech, clumsiness, tremor, mild rigidity, and hypokinetic facial expression appear. These symptoms are similar to those seen in Parkinson's disease, and they are typical of chronic manganese poisoning. ${ }^{12}$ 
After arc air gouging of manganese alloyed steel, two welders developed symptoms of the central nervous system that were an expression of high manganese exposure. ${ }^{1314}$ Since then, symptoms and signs of manganese intoxication have been documented from several welders. ${ }^{1516}$

Railway track welders are sometimes exposed to manganese ${ }^{111617}$ and this exposure has been associated with clinical signs of intoxication, ${ }^{16}$ as well as an increased prevalence of symptoms from the central nervous system compared with a control group of welders exposed to iron. ${ }^{11}$

The aim of the present investigation was to study with psychological and neurophysiological methods the effects on the nervous system of exposure to aluminium and manganese in welders. The exposed groups were compared with a control group comprising welders exposed to iron.

\section{Subjects and methods}

STUDY POPULATION

Welders exposed to aluminium

Welders exposed to aluminium were chosen from companies from which we had previous information on exposure to aluminium welding fumes. ${ }^{11}$ A questionnaire on exposure was sent to 86 welders with at least five years exposure to welding fumes containing aluminium. Responses were obtained from 74 of them $(86 \%)$. Altogether 38 welders exposed to aluminium, who according to the questionnaire had welded lead or high alloy manganese steel for a total of less than 10 hours, were chosen from companies within 250 kilometres of Stockholm.

\section{Railway track welders}

The railway track company had a register of the 240 employed railway track welders. The same questionnaire on exposure was sent to these welders. Altogether 202 (84\%) welders answered the questionnaire. Only those who had welded for five years or more were included in the study.

\section{Welders exposed to manganese}

Manganese alloy is sometimes overlayed in crossings with an electric electrode to increase the strength of the rail. Only 13 welders had been exposed to manganese and had welded for a total of more than 100 hours in high alloy manganese steel, and for a total of less than 25 hours in lead or aluminium. One welder refused to participate.

\section{Control welders}

As a control group 44 railway track welders were chosen, who according to the questionnaire had welded for a total of less than 25 hours in high alloy manganese steel, lead, or aluminium. Five welders refused to participate. During the investigation two welders scrutinised their memories carefully and reported a longer exposure to lead, 40 and 45 hours respectively.

According to representatives from the rail- way track company there was no selection to the two groups of railway welders.

\section{Methods}

Each subject was examined during one half day. The examination included questions on exposure and symptoms, psychological and neurophysiological investigations, and assessments of metals in blood and urine.

\section{Exposure}

Information on exposure time was taken from the questionnaire. The exposure to particles in the breathing zone of the welders was surveyed in the mid-1970s. The median exposure was $10 \mathrm{mg} / \mathrm{m}^{3}$ during aluminium metal inert gas (MIG) welding. ${ }^{18}$ The aluminium content was $40 \%$ of the total welding fume. ${ }^{19}$ Tungsten inert gas (TIG) welding was associated with a median exposure of $1 \mathrm{mg} / \mathrm{m}^{3} .^{18}$

The total number of welding hours $(T)$ has been calculated in the following way for MIG welders:

$$
\mathrm{T}=(\mathrm{TD} / 8) \times 1570 \times \mathrm{A}
$$

$\mathrm{TD}=$ reported number of exposed hours per day; $\mathrm{A}=$ reported number of exposed years.

The number of working hours a year was on average 1570 at the end of the 1970 s and during the $1980 \mathrm{~s}$, after exclusion of absenteeism. The TIG welding time has been divided by 10 to correspond to MIG welding exposure.

The railway track welders exposed to manganese worked with high alloy manganese electrodes (ESAB OK 86.08 and 86.28). According to the manufacturer, the fumes from these electrodes contained $22-24 \%$ manganese. Each welder has estimated his exposure time working with these electrodes.

The control group was mainly exposed to iron. The group was somewhat exposed to manganese, as almost all welders are. The exposure of the control welding group has been surveyed before and the fumes from the electrodes used contain 2-8\% manganese.

\section{Metals in blood and urine}

One sample of blood and one sample of urine were taken from each participant.

All materials used for sampling and storing were tested for the release of aluminium, lead, or manganese with a liquid containing $0.9 \%$ $\mathrm{NaCl}$. Syringes for blood sampling were Neofly, Viggo-Spectramed, JMS Singapore; tubes for storing blood were acid rinsed $5 \mathrm{ml}$ polypropylene with an external screwcap, Sarstedt, D5223, Nurnbrecht; and tubes for storing urine were acid rinsed $10 \mathrm{ml}$ polypropylene with an external screwcap.

Blood was taken from a cubital vein. A small volume of blood was washed through the needle before sampling. Urine sampling was performed after careful personal instructions to avoid external contamination. All samples were stored deep frozen until measurement.

Metal concentrations were measured by atomic absorption spectrometry (AAS) with a transverse heated electrothermal atomiser (THGA) with longitudinal Zeeman effect 
background correction (Perkin-Elmer Model $4100 \mathrm{ZL})$. For comparison, measurements were also performed with a Perkin-Elmer Model 3030 equipped with an HGA-500 electrothermal atomiser and Zeeman effect background correction. Hollow cathode lamps at recommended conditions and wavelengths were used. Tubes coated with pyrolytic graphite equipped with platforms and recommended modifiers were used throughout.

Blood samples were transferred to quartz Erlenmeyer flasks and concentrated $\mathrm{HNO}_{3}$ was added. The flasks were heated until most of the solution had been evaporated, and water was added to obtain a final mass one to two times that of the original blood sample. All manipulations, except for the measurement, were performed in a class 100 environment. A more detailed description of these procedures has been published. ${ }^{20}$

To $1 \mathrm{ml}$ of urine, $10 \mu \mathrm{l}$ of concentrated $\mathrm{HNO}_{3}$ was added, and all samples were screened for their aluminium content with atomic absorbtion spectroscopy. Samples containing high concentrations of aluminium were diluted 10 times with $1 \% \mathrm{HNO}_{3}$ and measured against aqueous standard solutions with $15 \mu \mathrm{g}$ of $\mathrm{Mg}\left(\mathrm{NO}_{3}\right)_{2}$ as modifier. Other samples were measured by the method of standard addition.

The accuracy of the method was checked by analysing Seronorm (batch 009024) and BioRad (Lyphocheck urine metals control Revell, 60901) for aluminium in urine and Seronorm serum 116 for aluminium in blood. Seronorm (trace elements in whole blood I, batch 01001) was used for lead, and lyophilised human serum for aluminium and manganese in blood. ${ }^{21}$ There was good agreement between observed and control concentrations for aluminium, lead, and manganese in blood. The observed urine concentration of aluminium was $25 \%$ lower than the external reference of Seronorm and was $71 \mu \mathrm{g} / 1$ for Bio-Rad with an acceptable mean (range) of $86(71-106) \mu \mathrm{g} / 1$.

The urinary metal concentrations were adjusted to creatinine and to concentrations after the shift. The concentrations of aluminium in urine of the exposed welders were divided by $\mathrm{e}^{-0.0015 \times \mathrm{T}}$ (for welders exposed for less than 10 years) to adjust the concentration in urine to an after shift level. $T=$ the number of hours from the end of the shift to the sampling. The correction for welders who had been exposed for 10 years or longer was: $\mathrm{e}^{-0.0015 \times \mathrm{T} .9}$

\section{Questionnaires}

Five main questionnaires were used.

Questionnaire A comprised questions on previous diseases, smoking, and alcohol habits. The questions on alcohol use were based on a slightly modified version of the Malmö modified Michigan alcoholic screening test. ${ }^{22}$ Questionnaire 16 (Q16) was used for symptoms of the nervous system. ${ }^{23}$

Questionnaire B was administered by computer and covered symptoms of local irritation and the central nervous system that existed at the time of questioning.

Questionnaire C was administered by computer and covered symptoms of the central and peripheral nervous systems during the past six months.

Questionnaire D contained questions on mood.

Questionnaire E was developed at the Institute of Occupational Health in Helsinki. ${ }^{24}$

\section{Psychological examinations}

The psychological test battery comprised seven computerised tests from the Swedish performance evaluation system (SPES) ${ }^{25}$ and three manual tests.

Simple reaction time-The simple reaction time measurement was a sustained attention task lasting for 11 minutes and measuring the response speed to an easily discriminated but temporally uncertain stimulus. Performance level was evaluated as the mean response latency (ms) for the last 10 minutes. The variability was evaluated as the SD of the individual distribution of latencies.

Finger tapping speed-The test for finger tapping speed measured the maximum speed of repetitive finger movement. Performance was evaluated as the mean number of taps for each index finger (dominant/non-dominant hand) from the last three of four 10 second trials.

Finger tapping endurance-This test of finger tapping endurance measured the number of taps performed with the index finger of the dominant hand during one 60 second trial.

Digit span-In this traditional test of short term memory capacity series of digits are presented on the screen. The digits are presented one at a time for one second, and the task is to reproduce the series on the keyboard. Depending on the correctness of the answer, the length of the next series is either increased or decreased. The test starts with a series of three digits and it is ended after six changes from correct to an incorrect answer.

Vocabulary-This is a traditional test of verbal comprehension. The task is to indicate among five alternatives which is the synonym of a key word. A total of 45 items, 15 nouns, 15 verbs, and 15 adjectives are presented. The words are presented in ascending order of difficulty and the number of correct answers is counted.

Tracking-The tracking test measures eyehand coordination. In this task a rectangular frame moves over the computer screen in a predefined pattern, which is unknown to the subject. His task is to continuously control the movement of the cursor, while using a joy stick to keep the cursor as close to the centre of the moving frame as possible. The test runs for six minutes, and the mean deviance from the centre of the frame is used as the performance measure.

Symbol digit - This is a revised version of a traditional test of perceptual speed. Two rows of symbols are presented on the screen. In the upper row each symbol is paired with a ran- 
domly arranged digit between one and nine. The task is to key in as fast as possible the digits corresponding to the symbols presented in a random order in the second row. Each item consists of nine pairs of randomly arranged symbols and digits, and a total of 10 items are presented. Performance is evaluated for the last six items of the test.

Cylinders-The test consists of two wooden plates with 60 holes in each plate. The task is to move cylinders from the holes in one plate to the other as fast as possible in 40 seconds, first with the dominant hand and then with the non-dominant hand. The test is performed twice and the number of cylinders is counted.

Olfactory threshold-Olfactory function was assessed with a test of olfactory threshold, Olfactolabs Kit No 11, containing PMcarbinol. The test comprises 18 bottles with increasing concentrations of PM-carbinol and an equal number of bottles containing mineral oil with no detectable smell. The concentrations are presented in a logarithmic scale as decismels (dS). The scale ranged from -30 to $+55 \mathrm{dS}$. One bottle with PM-carbinol and one without is presented and the task is to point out the smelling bottle. The test starts with concentrations in the normal range (0-5 dS). If the answer is correct the nearest lower concentration is presented and if wrong the nearest higher. Each concentration is presented three times and the olfactory threshold is defined as the concentration associated with three correct answers. ${ }^{26}$

Luria-Nebraska motor scale-Luria-Nebraska motor scale is a manually administered motor battery of tests. For this study tests, measuring speed and coordination have been chosen. Seven items were used, numbers $1,2,3,4,21$, 22 , and 23 . The time for each task was $10 \mathrm{sec}-$ onds. ${ }^{27}$

Item 1 The subject is required to touch the right thumb with the fingers of the right hand, starting with the index finger and ending with the little finger. The number of totally correct sequences is counted.

Item 2 The same as 1 with the left hand.

Item 3 This task is to alternately clench and stretch the right hand. The number of correct sequences is counted.

Item 4 The same as 3 with the left hand.

Item 21 The task starts with the right hand clenched and the left hand stretched. The hands should stretch and clench in such a way that the two hands never hold the same position. The number of correct sequences is counted.

Item 22 Both hands are placed on a table and the task is to tap the table twice with the right hand, immediately followed by one tap with the left hand. The number of correct sequences is counted.

Item 23 The same as 22 but with two taps with the left and one with the right hand.
(EEG) was performed according to clinical practice. The electrodes were placed according to the international 10/20-system. The subject was semireclined in a comfortable chair with the eyes closed. The interpretation was performed visually from paper recordings. The EEGs were classified as normal or pathological. The $\alpha$ activity was measured manually from the number of $\alpha$ waves during one second from three randomised samples of the resting curve.

Event related auditory evoked potential-Event related auditory evoked potential (P-300) examination was performed in a quiet room with the subject semireclined in a comfortable chair. Stimuli presented through headphones consisted of $50 \mathrm{~ms}$ beeps with a frequency of $1000 \mathrm{~Hz}$ (repetitive) or $2000 \mathrm{~Hz}$ (randomised). The interval between stimuli was two seconds, and $25 \%$ of the beeps were of the randomised type. The subject was instructed to count the number of randomised beeps and keep the accumulated sum in mind. The total number of beeps was 512 . Latency to the P300 peak was measured.

Brainstem auditory evoked potential - Stimuli for the brainstem auditory evoked potential consisted of brief $(0.05 \mathrm{~ms})$ clicks through one headphone with a frequency of $10 \mathrm{clicks} / \mathrm{sec}-$ ond. The response was recorded bipolarly with electrode positions at the vertex and behind the ipsilateral ear (mastoid process). Latencies to peaks I, II, and V (according to clinical standard) were measured along with differences I-III, III-V, and I-V.

Diadochokinesometry-Diadochokinesis (the ability to perform rapidly alternating movements with one limb, such as supination/pronation of the forearm) makes high demands on the coordination of activity in different muscle groups. This coordination is produced by the extrapyramidal nervous system, the function of which is impaired in Parkinson's disease. A test of diadochokinesis would therefore be suitable for showing early (subclinical) signs of parkinsonism. Alternating wrist movements have previously been used as a test of pharmacological treatment of Parkinson's disease (Lindblom, unpublished report 1989). The recording equipment was the same as that used by Lindblom (a rotatable handle and the movements were recorded by a pen recorder). The subjects were told to turn the handle as fast as possible so that the end points corresponded to an almost maximal supination and pronation, respectively, during 30 seconds. Both hands were examined. Three periods of 10 full turns (cycles) were used from each series to calculate the mean values of frequency (number of full turns a second) and amplitude. Regularity in frequency and amplitude was used as a check for adequate performance. Otherwise there was no way of checking the maximal volition.

Statistical calculations were performed with 
Table 1 Medians (ranges) of reported duration of exposure and measured blood and

\begin{tabular}{|c|c|c|c|}
\hline Exposure measure & $\begin{array}{l}\text { Aluminium } \\
\text { welders } \\
(n=38)\end{array}$ & $\begin{array}{l}\text { Manganese } \\
\text { welders } \\
(n=12)\end{array}$ & $\begin{array}{l}\text { Control } \\
\text { welders } \\
(n=39)\end{array}$ \\
\hline \multicolumn{4}{|l|}{ Aluminium: } \\
\hline Hours worked & $\begin{array}{l}7065 \\
(1766-21980)\end{array}$ & $\begin{array}{l}0 \\
(0-20)\end{array}$ & $\begin{array}{l}0 \\
(0-20)\end{array}$ \\
\hline Blood concentration $(\mu \mathrm{g} / \mathrm{l})$ & $\begin{array}{l}3 \cdot 0 \\
(\mathrm{dl}-27)\end{array}$ & $\begin{array}{l}<1 \\
(\mathrm{dl}-11)\end{array}$ & $\begin{array}{l}\mathrm{i} \cdot 0 \\
(\mathrm{dl}-11)\end{array}$ \\
\hline Urine concentration $(\mu \mathrm{g} / \mathrm{l})$ & $\begin{array}{l}22 \cdot 0 \\
(4-255)\end{array}$ & $\begin{array}{l}2 \cdot 0 \\
(1-7)\end{array}$ & $\begin{array}{l}3 \cdot 0 \\
(\mathrm{dl}-26)\end{array}$ \\
\hline Urine concentration ( $\mu \mathrm{g} / \mathrm{g}$ creatinine) & $\begin{array}{l}24 \cdot 0 \\
(4 \cdot 5-162)\end{array}$ & $\begin{array}{l}4 \cdot 4 \\
(1 \cdot 2-18 \cdot 2)\end{array}$ & $\begin{array}{l}4 \cdot 7 \\
(\mathrm{dl}-24 \cdot 9)\end{array}$ \\
\hline \multicolumn{4}{|l|}{ Manganese: } \\
\hline Hours worked & $\begin{array}{l}0 \\
(0-0)\end{array}$ & $\begin{array}{l}270 \\
(100-1760)\end{array}$ & $\begin{array}{l}4 \\
(0-25)\end{array}$ \\
\hline Blood concentration $(\mu \mathrm{g} / 1)$ & $\begin{array}{l}8 \cdot 0 \\
(2-17)\end{array}$ & $\begin{array}{l}8 \cdot 5 \\
(5-14)\end{array}$ & $\begin{array}{l}7 \cdot 0 \\
(2-16)\end{array}$ \\
\hline \multicolumn{4}{|l|}{ Lead: } \\
\hline Hours worked & $\begin{array}{l}0 \\
(0-5)\end{array}$ & $\begin{array}{l}6 \cdot 7 \\
(0-20)\end{array}$ & $\begin{array}{l}2 \\
(0-45)\end{array}$ \\
\hline Blood concentration $(\mu \mathrm{g} / \mathrm{l})$ & $\begin{array}{l}36 \cdot 0 \\
(17-92)\end{array}$ & $\begin{array}{l}37 \cdot 5 \\
(13-60)\end{array}$ & $\begin{array}{l}42 \cdot 0 \\
(8-76)\end{array}$ \\
\hline
\end{tabular}

$\mathrm{dl}=$ Detection limit for the method of analysis $(<1 \mu \mathrm{g} / \mathrm{l})$.

SPSS on Macintosh. One way analysis of variance was used to test overall differences in all effect measures. In a second step Duncan's test was used to identify groups that differed. The level of significance for Duncan's test was chosen to be $P<0.05$. Only the Duncan's tests are presented under results.

Differences in frequencies have been calculated with Fisher's exact test.

Where group differences had been found, possible dose-effect relations were calculated as correlations between dose estimates and effect measures.

To further study possible dose-effect relations of aluminium exposure, the group of welders exposed to aluminium was merged with the control group. This constructed group was divided into three categories of

Table 2 Means (SDs) of symptoms and mood in the three welder groups

\begin{tabular}{|c|c|c|c|}
\hline Questionnaire (index) & $\begin{array}{l}\text { Aluminium } \\
\text { welders } \\
(n=38)\end{array}$ & $\begin{array}{l}\text { Manganese } \\
\text { welders } \\
(n=12)\end{array}$ & $\begin{array}{l}\text { Control } \\
\text { welders } \\
(n=39)\end{array}$ \\
\hline \multicolumn{4}{|l|}{ Questionnaire A: } \\
\hline Q16 & $1 \cdot 84(2 \cdot 2)$ & $2 \cdot 75(2.5)$ & $1 \cdot 87(2 \cdot 5)$ \\
\hline Ästenia 1 & $1 \cdot 13(1 \cdot 1)$ & $1 \cdot 33(1 \cdot 0)$ & $1 \cdot 15(1 \cdot 3)$ \\
\hline Astenia 2 & $1 \cdot 21(1 \cdot 2)$ & $1.33(1.0)$ & $1.21(1.5)$ \\
\hline Dizziness & $0.21(0.5)$ & $0 \cdot 17(0 \cdot 6)$ & $0.05(0.2)$ \\
\hline Tremor & $0.21(0 \cdot 6)$ & $0 \cdot 17(0.6)$ & $0.26(0.6)$ \\
\hline PNS & $0 \cdot 26(0 \cdot 6)$ & $\star 1.00(1.0)$ & $0.38(0.6)$ \\
\hline \multicolumn{4}{|l|}{ Questionnaire B (acute symptoms): } \\
\hline CNSt & $\star 0.35(0.4)$ & $0 \cdot 21(0 \cdot 2)$ & $0 \cdot 20(0 \cdot 3)$ \\
\hline Irritation $\uparrow$ & $0.42(0.5)$ & $0.38(0 \cdot 3)$ & $0.38(0.4)$ \\
\hline \multicolumn{4}{|l|}{ Questionnaire C (symptoms 6 months): } \\
\hline Total sum of symptoms ratings & $16 \cdot 3(8 \cdot 7)$ & $21 \cdot 3(10 \cdot 3)$ & $17 \cdot 2(13 \cdot 5)$ \\
\hline Fatiguef & $0.78(0.5)$ & $0.88(0.4)$ & $0.59(0.5)$ \\
\hline Sleep disturbances $\dagger$ & $0.54(0.4)$ & $0.77(0.4)$ & $0.53(0.5)$ \\
\hline Stomach symptoms $\dagger$ & $0.38(0.4)$ & $0.40(0.5)$ & $0.31(0.3)$ \\
\hline Airway symptoms $\dagger$ & $0 \cdot 18(0 \cdot 3)$ & $0 \cdot 28(0 \cdot 3)$ & $0.33(0.7)$ \\
\hline Neurological symptoms $\dagger$ & $0.26(0 \cdot 3)$ & $0.50(0.5)$ & $0.30(0 \cdot 4)$ \\
\hline Psychological symptoms $†$ & $0.51(0.3)$ & $0.53(0.3)$ & $0.46(0.4)$ \\
\hline Pains and achest & $\star 0.35(0.3)$ & $0.73(0.5)$ & $0.65(0.6)$ \\
\hline Ear and eye symptoms $†$ & $0.22(0.4)$ & $0.13(0 \cdot 2)$ & $0.32(0.4)$ \\
\hline Skin symptoms $\dagger$ & $0.24(0.5)$ & $0.33(0.5)$ & $0.46(0.8)$ \\
\hline Heart symptoms $\dagger$ & $0.11(0 \cdot 3)$ & $0 \cdot 17(0.4)$ & $0.08(0.3)$ \\
\hline White fingerst & $0.32(0 \cdot 7)$ & $0.42(0.7)$ & $0.44(0.8)$ \\
\hline \multicolumn{4}{|l|}{ Questionnaire D (mood): } \\
\hline Activity & $19 \cdot 1(3 \cdot 4)$ & $18 \cdot 2(4 \cdot 0)$ & $19 \cdot 7(3 \cdot 8)$ \\
\hline Stress & $18 \cdot 1(5 \cdot 0)$ & $19 \cdot 3(3.6)$ & $20 \cdot 1(4 \cdot 1)$ \\
\hline \multicolumn{4}{|l|}{ Questionnaire E (Helsinki): } \\
\hline Emotional lability & $1.26(0.3)$ & $1 \cdot 28(0 \cdot 2)$ & $1 \cdot 22(0 \cdot 3)$ \\
\hline Fatigue & $1.65(0.4)$ & $1.82(0.5)$ & $1.61(0.5)$ \\
\hline Sensory and motor symptoms & $1 \cdot 14(0 \cdot 2)$ & $\star 1.39(0.5)$ & $1 \cdot 19(0 \cdot 3)$ \\
\hline Sleep disturbances & $1.41(0.4)$ & $\star 1.67(0.5)$ & $1.38(0.4)$ \\
\hline Memory and concentration & $1.47(0.6)$ & $1.71(0.5)$ & $1.58(0.6)$ \\
\hline Somatic complaints & $1 \cdot 24(0 \cdot 3)$ & $1.30(0.2)$ & $1.31(0 \cdot 3)$ \\
\hline
\end{tabular}

*Groups that differed significantly from the control welders in the Duncan's test $(P<0.05)$ tIndividual means of ratings. exposure. The borders of these categories were the 50th and 75th percentiles.

All statistical analyses of symptoms have been based on indices that represent groups of symptoms. These indices have been regarded as continuous variables.

\section{Results}

The mean ages in the groups of welders were almost the same. The mean age was $39 \cdot 0$ (range 26-56) years in the welders exposed to aluminium, $40 \cdot 4$ (range 27-61) years in the welders exposed to manganese, and $40 \cdot 1$ years (23-59) among the control welders. The welders exposed to manganese had worked more years with welding in general $(19.5$ years) than the welders exposed to aluminium $(17 \cdot 1$ years $)$ and the control welders $(13 \cdot 8$ years).

The smoking habits differed somewhat between the groups. In the group of welders exposed to aluminium $34 \%$ smoked, in the manganese group $17 \%$, and in the control group $27 \%$. About $50 \%$ were ex-smokers.

Among the welders exposed to aluminium $24 \%$ drank beer, wine, or spirits every weekend. In the manganese exposed group $17 \%$ and in the control group $29 \%$ had the same habit.

Three control welders had experienced head trauma. One welder had been unconscious for less than one hour, and one for a somewhat longer period. One welder exposed to manganese had been unconscious for less than one hour.

None of the participants had been occupationally exposed to solvents. Two control welders had been exposed to solvents to some extent during leisure activities.

The only subject who had ingested antacids containing aluminium daily during the past 10 years was a control welder. This welder had the highest urinary concentration of aluminium among the controls, $26 \mu \mathrm{g} / 1$.

\section{EXPOSURE}

Table 1 shows the reported duration of exposure and blood and urine concentrations of aluminium, manganese, and lead. The urinary aluminium concentrations of the welders exposed to aluminium were about seven times higher than the control welders. The calculated median (range) concentration of aluminium after the shift was $22 \cdot 4(4-322) \mu \mathrm{g} / \mathrm{l}$. The corresponding median (range) concentration adjusted for creatinine was 24.4 (4.5-164) $\mu \mathrm{g} / \mathrm{g}$ creatinine. The median time between the end of the shift and sampling was 32 (mean (range) 177 (20-3956)) hours.

The welders exposed to manganese did not have higher concentrations of manganese in blood than the other groups.

There was no correlation between the duration of exposure to aluminium from welding (total number of hours) and the concentration of aluminium in blood $(r=0 \cdot 10, \mathrm{P}=0.58)$. However, there was an indication of a correlation between the duration of exposure to aluminium from welding and the concentration 
Table 3 Means (SDs) regarding the performance measures from the psychological testing in the three welder groups

\begin{tabular}{|c|c|c|c|}
\hline Performance variable & $\begin{array}{l}\text { Aluminium } \\
\text { welders } \\
(n=38)\end{array}$ & $\begin{array}{l}\text { Manganese } \\
\text { welders } \\
(n=12)\end{array}$ & $\begin{array}{l}\text { Control } \\
\text { welders } \\
(n=39)\end{array}$ \\
\hline \multicolumn{4}{|l|}{ Tapping speed (n of taps): } \\
\hline Dominant hand & $63.8(8 \cdot 8)$ & $63 \cdot 7(7 \cdot 1)$ & $66 \cdot 1(8 \cdot 3)$ \\
\hline Non-dominant hand & $\star 57 \cdot 3(10 \cdot 4)$ & $\star 54 \cdot 3(7 \cdot 7)$ & $62 \cdot 3(9 \cdot 3)$ \\
\hline Tapping endurance ( $n$ of taps) & $299 \cdot 2(62 \cdot 3)$ & $286 \cdot 1(30 \cdot 5)$ & $295 \cdot 1(47 \cdot 1)$ \\
\hline \multirow{2}{*}{\multicolumn{4}{|c|}{$\begin{array}{l}\text { Luria-Nebraska motor scale } \\
\text { (n of sequences) task No: }\end{array}$}} \\
\hline & & & \\
\hline 1 & $7.9(1.8)$ & $7 \cdot 3(1 \cdot 2)$ & $7 \cdot 8(1.5)$ \\
\hline 2 & $7 \cdot 6(1.7)$ & $\star 6.8(1 \cdot 1)$ & $7.9(1.6)$ \\
\hline 3 & $\star 19 \cdot 1(5 \cdot 2)$ & $22.5(6 \cdot 3)$ & $21.5(4.9)$ \\
\hline 4 & $\star 19.7(5 \cdot 2)$ & $22 \cdot 8(6 \cdot 3)$ & $22 \cdot 7(5 \cdot 2)$ \\
\hline 21 & $13.9(4.3)$ & $13 \cdot 1(3 \cdot 2)$ & $15 \cdot 3(4 \cdot 5)$ \\
\hline 22 & $13 \cdot 1(5 \cdot 1)$ & $\star 10.5(2.7)$ & $14 \cdot 7(4 \cdot 8)$ \\
\hline 23 & $11.9(3.6)$ & $10.7(3.0)$ & $12 \cdot 5(3 \cdot 0)$ \\
\hline \multicolumn{4}{|l|}{ Pegboard ( $n$ of pegs moved): } \\
\hline Dominant hand & $\star 43.5(3.8)$ & $\star 42 \cdot 5(2 \cdot 7)$ & $45 \cdot 3(3 \cdot 7)$ \\
\hline Non-dominant hand & $40.8(3.5)$ & $\star 39.0(2.5)$ & $41 \cdot 8(3 \cdot 7)$ \\
\hline Tracking (mean deviation) & $12 \cdot 6(4 \cdot 0)$ & $11.4(3.0)$ & $11 \cdot 7(4 \cdot 0)$ \\
\hline \multicolumn{4}{|l|}{ Simple reaction time: } \\
\hline Level (ms) & $239 \cdot 5(37 \cdot 8)$ & $242 \cdot 3(20 \cdot 0)$ & $228 \cdot 7(22 \cdot 7)$ \\
\hline Variability (ms) & $45.8(20.6)$ & $52 \cdot 2(15 \cdot 2)$ & $43 \cdot 3(13 \cdot 1)$ \\
\hline \multicolumn{4}{|l|}{ Symbol digit coding: } \\
\hline Latency per digit(s) & $3 \cdot 1(0.6)$ & $3.2(0.4)$ & $2.9(0.6)$ \\
\hline \multicolumn{4}{|l|}{ Digit span forwards: } \\
\hline Mean ( $\mathrm{n}$ of digits) & $6 \cdot 3(1 \cdot 0)$ & $6 \cdot 0(0 \cdot 7)$ & $6 \cdot 6(1 \cdot 4)$ \\
\hline Maximum ( $\mathrm{n}$ of digits) & $7 \cdot 6(0.9)$ & $7 \cdot 0(0 \cdot 8)$ & $7 \cdot 4(2 \cdot 0)$ \\
\hline Vocabulary (n correct) & $21 \cdot 3(9 \cdot 3)$ & $19 \cdot 7(8 \cdot 0)$ & $22 \cdot 8(9 \cdot 7)$ \\
\hline Smell threshold (dS) & $6 \cdot 2(8 \cdot 5)$ & $9 \cdot 5(13 \cdot 1)$ & $5.8(10.0)$ \\
\hline
\end{tabular}

*Groups that differed significantly from the control welders in the Duncan's test $(P<0.05)$.

of aluminium in urine $(r=0 \cdot 26, \mathrm{P}=0 \cdot 11)$.

\section{SYMPTOMS}

Several questionnaires were used to measure the occurrence of symptoms from the central and peripheral nervous system (table 2). The welders exposed to aluminium reported more symptoms from the central nervous system at the time of the test and the most prominent symptom was fatigue. These welders also reported fewer symptoms of pain during the past six months than the control welders. There were more symptoms from the peripheral nervous system, sensory and motor symptoms, and disturbances of sleep among the welders exposed to manganese than among the control welders. These differences remained after adjustment for age, blood lead concentrations, alcohol consumption, and alcohol habits.

PSYCHOLOGICAL EXAMINATIONS

Table 3 shows the results from the three groups of welders for the psychological test battery. The welders exposed to aluminium achieved a significantly lower score in four of the tests than did the control group, and the

Table 4 Mean values for symptoms and performance in subgroups of the merged group (aluminium exposed and control welders, $n=77$ )

\begin{tabular}{|c|c|c|c|}
\hline \multirow[b]{2}{*}{ Effect variable } & \multicolumn{3}{|c|}{ Exposure category (urinary aluminium $(\mu g / l)$ ) } \\
\hline & $\begin{array}{l}\leqslant 50 \text { th } \\
\text { percentile } \\
\leqslant 8 \cdot 0 \mu g / l \\
(n=39)\end{array}$ & $\begin{array}{l}\text { 50th-75th } \\
\text { percentile } \\
>8 \cdot 0-\leqslant 24 \cdot 0 \mu \mathrm{g} / \mathrm{l} \\
(n=19)\end{array}$ & $\begin{array}{l}>75 t h \\
\text { percentile } \\
>24 \cdot 0 \mu \mathrm{g} / \mathrm{l} \\
(n=19)\end{array}$ \\
\hline \multirow{3}{*}{$\begin{array}{l}\text { Acute symptoms from the central } \\
\text { nervous system } \\
\text { Symptoms (6 months) pains and aches } \\
\text { Tapping (speed) non-dominant hand } \\
\text { Luria-Nebraska motor scale task no: } \\
3 \\
4 \\
\text { Pegboard dominant hand } \\
\text { Diadochokinesis dominant hand, } \\
\text { amplitude }\end{array}$} & $\begin{array}{r}0.20 \\
0.63 \\
63 \cdot 2^{\star}\end{array}$ & $\begin{array}{c}0 \cdot 19 \\
0 \cdot 43 \\
57 \cdot 1\end{array}$ & $\begin{array}{c}0.50 \dagger \\
0.32 \dagger \\
55.7\end{array}$ \\
\hline & $\begin{array}{l}21 \cdot 1 \\
22 \cdot 2 \\
44 \cdot 9\end{array}$ & $\begin{array}{l}20 \cdot 8 \\
21 \cdot 6 \\
42 \cdot 9\end{array}$ & $\begin{array}{l}18 \cdot 2 \\
18 \cdot 9 \dagger \\
45 \cdot 1\end{array}$ \\
\hline & $97 \cdot 3$ & $104 \cdot 8$ & $104 \cdot 1$ \\
\hline
\end{tabular}

${ }^{\star}$ Group that differs significantly from both the other groups; tgroup that differs significantly from the group with the lowest exposure. welders exposed to manganese achieved a lower score in five of the tests. The relative differences in performance varied between $4 \%$ and $12 \%$.

NEUROPHYSIOLOGICAL EXAMINATIONS

The visual interpretation of the paper recorded electroencephalography (EEG) did not show any significant differences between the welding groups. The proportion of pathological EEGs was $29 \%$ among the welders exposed to aluminium, 33\% among the welders exposed to manganese, and 13\% among the control welders.

There was no difference between welders exposed to aluminium and control welders in latency of event related auditory evoked potential (P-300), 311.4 ms and 309.4, respectively. However, the welders exposed to manganese $(332.5 \mathrm{~ms})$ had a significantly longer latency than the controls.

There was no difference between any of the welding groups for latencies of the brainstem auditory evoked potential.

The welders exposed to aluminium had a significantly higher amplitude of the dominant hand in the diadochokinesometric investigation than did the control welders, 104.6 and $97 \cdot 2$ (arbitrary units), respectively. There was no significant difference between the measured frequencies, 2.69 and $2.86(\mathrm{~Hz})$, respectively. The non-dominant hand showed the same tendency but the differences were not significant. There were no significant differences between the welders exposed to manganese and the controls.

\section{DOSE-EFFECT RELATION}

A significant difference was found between the welders exposed to aluminium and controls in seven variables altogether. These variables were investigated for possible dose effect relations. The only significant correlation was found between urinary aluminium concentration and the occurrence of symptoms of the central nervous system. No significant correlations were found among the welders exposed to manganese.

To further investigate the possible doseeffect relation of aluminium exposure, the group of welders exposed to aluminium was merged with the control group. This merged group was divided into three categories of exposure. The borders of these categories were the 50th and 75th percentiles according to urinary concentrations of aluminium. Three variables showed a significant dose-effect relation according to the analysis of variance (table 4). The median urinary concentration of aluminium was $59 \mu \mathrm{g} / 1$ in the highest exposure group. In five welders the urinary concentration exceeded $100 \mu \mathrm{g} / \mathrm{l}$. A similar dose-effect relation was also found when the urinary concentrations were adjusted to $\mu \mathrm{g} / \mathrm{g}$ creatinine. The 75 th percentile was $24.5 \mu \mathrm{g} / \mathrm{g}$ creatinine. A dose-effect relation was also calculated for the number of hours exposed to aluminium and blood concentrations. An aluminium exposure exceeding 7028 hours had the same effect as a urinary aluminium concentration 
above $24 \mu \mathrm{g} / 1$. The concentration of aluminium in blood did not relate either to symptoms or to performance.

\section{Discussion}

ALUMINIUM

The most prominent symptom among the welders exposed to aluminium in this study was fatigue at the time of the test. However, fatigue was not a prominent symptom in previous studies of Swedish welders ${ }^{11}$ nor Finnish welders. $^{24}$

In a previous investigation of welders exposed to aluminium, an increased occurrence of symptoms such as difficulties in concentrating and depression was reported. ${ }^{11}$ With information from a previuos study on the relation between air concentration of aluminium, duration of exposure, and urinary concentration, a urinary aluminium concentration of about $250 \mu \mathrm{g} / \mathrm{l}$ was calculated. ${ }^{28}$ This urinary concentration is four to five times higher than the concentration in the current study, which did not show an increased prevalence of these particular symptoms (Q16).

In our group of welders exposed to aluminium performance decrements in five motor tests were also found. In the group of welders with the highest exposure to aluminium, with a median urinary aluminium concentration of $59 \mu \mathrm{g} / \mathrm{l}$, a lower performance was detected for tapping (non-dominant hand) and LuriaNebraska motor scale, item 4. An impaired performance of tapping has been reported in 25 workers from an aluminium smelting plant. ${ }^{29}{ }^{30}$ This finding is however difficult to interpret, as these workers were not a random sample, but went to an occupational medicine clinic because of suspicion of a work related illness.

In a Norwegian study of retired potroom workers exposed to aluminium a test for tremor discriminated significantly between exposed and control workers. The mean urinary aluminium concentration of the 14 potroom workers was $13 \mu \mathrm{g} / 1$, but the average interval from last exposure to examination was 22 days. The mean urinary aluminium concentration of the non-retired colleagues working in the same factory was $54 \mu \mathrm{g} / 1,{ }^{31}$ which is probably a better estimate of the previous exposure for these retired potroom workers.

Seventeen Finnish welders exposed to aluminium performed normally in a battery of neuropsychological tests according to the clinical norms for these tests. They had been exposed for four years and their mean (SD) urinary aluminium concentration was $2 \cdot 8$ $\mu \mathrm{mol} / 1(76 \mu \mathrm{g} / \mathrm{l})$. This mean was based on four weekly urine samples taken during the summer vacation from 11 welders and on urine samples taken on the day of examination from six welders. Despite the fact that these welders exposed to aluminium displayed normal performances according to test norms, negative relations were found between urinary concentrations of aluminium and short term memory, learning, and attention. ${ }^{24}$ The estimated urinary concentration of aluminium after the shift, according to our previous assumptions, ${ }^{9}$ would be about $100 \mu \mathrm{g} / 1$ based on an interval between exposure and sampling of seven days (168 hours). This concentration is most probably an underestimation of exposure. A decreased memory function has also been found among foundry workers exposed to aluminium. ${ }^{32}$ Our study, however, did not show any clear effects in similar tests.

Among patients on dialysis with a mean serum concentration of $59 \mu \mathrm{g} / \mathrm{l}$ aluminium, the response times of the symbol digit coding test were slower than among controls. ${ }^{33}$ This serum concentration of aluminium would correspond to a urinary concentration of about $300 \mu \mathrm{g} / 1$ in people with a normal kidney function. ${ }^{8}$ In the current study we did not discover any effects in a similar test.

Between 1944 and 1979 McIntyre powder, consisting of finely ground aluminium and aluminium oxides, was used as a prophylactic agent against silicotic disease in mines in northern Ontario. The miners inhaled the particles for 10 minutes before each underground shift. In the late 1980 s 261 miners exposed to aluminium were compared with 346 unexposed miners. Three cognitive state tests were performed. Of the unexposed miners $4 \%$ showed impaired cognitive function, as did $10 \%$ of the miners with $0.5-9.9$ years of exposure, $15 \%$ of the miners with $10-19.9$ years of exposure, and $20 \%$ of miners with exposure longer than 20 years. ${ }^{34}$ Unfortunately, biological exposure data have not yet been published from this study.

The aluminium concentrations found in our study are possibly lower than the true concentrations, as observed values were $25 \%$ lower than external control values.

The dose-dependent effect on motor function, which was found in this study, and the tremor found among the Norwegian potroom workers $^{31}$ appeared at about the same dose and concentration of aluminium in urine. Still, further studies are necessary to confirm this finding.

\section{MANGANESE}

The welders exposed to manganese in this study reported more symptoms from the peripheral nervous system and also more frequent sensory and motor symptoms than did the control welders. Such symptoms have been more frequently found also among other groups of workers exposed to manganese. ${ }^{35}$ Furthermore, our study of welders showed a higher prevalence of disturbances of sleep among the welders exposed to manganese. Insomnia has also been noted in several other studies. ${ }^{163536}$ Fatigue, finger tremor, and tinnitus were not prominent symptoms in our study but have been reported by others. ${ }^{35} 36$

Swedish railway track welders exposed to manganese had a higher prevalence of symptoms from the central nervous system than did a control group of welders exposed to iron. ${ }^{11}$ The same questionnaire (Q16) was used in this study and showed a higher, but not significantly higher, prevalence of these symptoms.

Among German welders exposed to $1-4$ 
$\mathrm{mg} / \mathrm{m}^{3}$ of manganese for an average of 16 years, a positive relation was found between the number of exposed years and a reaction time index. ${ }^{37}$ A prolonged slowed reaction time has been seen in several other studies of workers exposed to manganese. ${ }^{36} 3839$ However, no significant prolongation of the reaction time was found in our study. This may be due to the short exposure time.

A Swedish study of 30 foundry workers exposed to manganese reported inferior performance in the exposed group compared with 60 non-exposed workers. The exposure concentration was rather low, with a geometric mean (range) of $0 \cdot 15(0 \cdot 19-1 \cdot 39) \mathrm{mg} / \mathrm{m}^{3} .39$ Finger tapping performance was reduced in this study of Swedish foundry workers, in Italian ferroalloy plant workers,,$^{40}$ and in the current study of welders.

The motor disturbances found in the LuriaNebraska motor scale was in agreement with the findings by Mergler and colleagues. ${ }^{35}$ Our study disclosed a difference between the groups in hand dexterity (cylinders). This finding is not supported by the studies of Mergler et $a l^{35}$ and Wennberg et al. ${ }^{39}$ One possible explanation of this difference is a better comparability between the exposed group and the control group, both being welders. This design feature might have increased the sensitivitity of the study to find group differences.

In a review of previous studies, relatively consistent effects have been described about memory functions. ${ }^{41} \mathrm{~A}$ tendency towards such an effect was also found in the present study.

A facilitation effect on the olfactory perception (a lowered threshold) has previously been found in workers exposed to manganese. ${ }^{35}$ Such an effect could not be found in this study.

The longer latency of event related auditory evoked potential (P-300) found in this study was similarly found as a tendency in the study of Swedish foundry workers exposed to manganese. ${ }^{39}$

In this study calculations of accumulated doses could not be performed because of the scarcity of data. Roels and coworkers made such calculations in an investigation of 92 workers exposed to $\mathrm{MnO}_{2}$ dust in a dry alkaline battery factory and 101 workers in a matched control group. The workers' performances on tasks measuring visual reaction time, eye-hand coordination, hand steadiness, and audioverbal short term memory were investigated. An increased risk of peripheral tremor was found when the lifetime integrated exposure to manganese dust exceeded 3575 $\mu \mathrm{g} \mathrm{Mn} / \mathrm{m}^{3} \times$ year for total dust or $730 \mu \mathrm{g}$ $\mathrm{Mn} / \mathrm{m}^{3} \times$ year for respirable dust. ${ }^{38}$

The welders exposed to manganese were very few $(n=12)$. The total number of hours exposed to manganese was also low. The median exposure was 270 hours, and no welder reported more than 1760 hours, which is slightly more than one year. It is remarkable that a poorer performance was detected in such a small group of welders with such low exposure who had worked presumably in a well ventilated outdoor atmosphere. The welding fumes generated from the high alloy manganese electrodes contain $22-24 \%$ manganese. So far, only a few exposure measurements have been performed during this particular work. Two time weighted averages when welding with the coated electrode ESAB OK 86.28 were 0.1 and $0.5 \mathrm{mg} / \mathrm{m}^{3}$. Welding with a flux cored wire electrode was associated with a time weighted average of $0.9 \mathrm{mg} / \mathrm{m}^{3}$.

The differences in symptoms that were found between the welders exposed to manganese and the controls in this study are in agreement with what is to be expected from previous studies of subjects exposed to manganese. The differences regarding performance refer to motor function and these differences are also in agreement with previous investigations although these exposed groups have generally been exposed for a longer time and most often to higher levels. ${ }^{41}$

\section{COMPARABILITY OF THE STUDY GROUPS}

The three groups of welders are comparable for education and social background. According to representatives from the railway track company, there has not been any biased selection to any of the track welding groups. The alcohol habits were about the same among the welders exposed to aluminium and controls, and a somewhat lower consumption was reported by the welders exposed to manganese. The group differences found were not affected by adjustment for alcohol consumption. Age has been discussed as a possible influencing factor on some tests. However, adjustment for age did not change any results. The blood concentration of lead did not differ between the groups and all welders had a concentration below $100 \mu \mathrm{g} / \mathrm{l}$, which is normal for occupationally non-exposed groups. ${ }^{42}$ As expected adjustment for blood lead concentrations did not change the results. Previous head trauma was somewhat more common among control welders. This was not taken into account in the analysis, and the effect, probably minor, would have underestimated group differences.

Altogether, the comparability between the studied groups is probably better in the present investigation than in most other studies where psychological performance was the effect measure.

\section{Conclusion}

Subtle disturbances in motor function have been found in this and other groups of workers exposed to aluminium when urinary concentrations have been around $50 \mu \mathrm{g} / 1$. These results indicate further investigations of other workers exposed to this metal. Measurements should be taken to decrease the aluminium exposure among welders.

Consistent disturbances in motor function shown by several tests in our study, lead to the conclusion that manganese is most likely to be the cause, despite the low concentrations and short duration of exposure. Thus, the work environment for these welders working with high alloy manganese electrodes should be improved. 
1 Sjögren B, Elinder C-G. Aluminum and its compounds. In: Zenz C, Dickerson OB, Horvath EP, eds. Occupational medicine, 3rd edition. St Louis: Mosby-Year Book, 1994: 458-65.

2 Alfrey AC, LeGendre GR, Kaehny WD. The dialysis encephalopathy syndrome, possible aluminum intoxication. N Engl $\mathcal{F}$ Med 1976;294:184-8.

3 Schreeder MT, Favero MS, Hughes JR, Petersen NJ, Bennett PH, Maynard JE. Dialysis encephalopathy and aluminum exposure: an epidemiologic analysis. $\mathcal{f}$ Chron Dis 1983;36:581-93.

4 Alfrey AC, Froment DC. Dialysis encephalopathy. In: De Broe M, Coburn JW, eds. Aluminum and renal failure, developments in nephrology vol 26. Dordrecht: Kluwer Acvelopments in nephrology vol 26.

5 McLaughlin AIG, Kazantzis G, King E, Teare D, Porter RJ, Owen R. Pulmonary fibrosis and encephalopathy RJ, Owen R. Pulmonary fibrosis and encephalopathy
associated with the inhalation of aluminium dust. $B r f$ associated with the inhal
Ind Med 1962;19:253-63.

6 Sjögren B, Ljunggren KG, Almkvist O, Frech W, Basun H. Aluminosis and dementia [letter]. Lancet 1994;344: 1154.

7 Ljunggren KG, Lidums V, Sjögren B. Blood and urine concentrations of aluminium among workers exposed to aluminium flakes. $\mathrm{Br} \mathcal{F}$ Ind Med 1991;48:106-9.

8 Sjögren B, Lundberg I, Lidums V. Aluminium in the blood and urine of industrially exposed workers. $\mathrm{Br} \mathcal{F}$ Ind $\mathrm{Med}$ 1983;40:301-4.

9 Sjögren B, Elinder CG, Lidums V, Chang G. Uptake and urinary excretion of aluminum among welders. Int Arch Occup Environ Health 1988;60:77-9.

10 Elinder CG, Ahrengart L, Lidums V, Pettersson E, Sjögren $B$. Evidence of aluminium accumulation in aluminium welders. Br f Ind Med 1991;48:735-8.

11 Sjögren B, Gustavsson P, Hogstedt C. Neuropsychiatric symptoms among welders exposed to neurotoxic metals. Br f Ind Med 1990;47:704-7.

12 Politis MJ, Schaumburg HH, Spencer PS. Neurotoxicity of selected chemicals. In: Spencer PS, Schaumburg $\mathrm{HH}$, eds. Experimental and clinical neurotoxicology. Baltimore: Williams and Wilkins, 1980:613-30.

13 Tanaka S, Lieben J. Manganese poisoning and exposure in Pennsylvania. Arch Environ Health 1969;19:674-84.

14 Whitlock CM, Amuso SJ, Bittenbender JB. Chronic neurological disease in two manganese steel workers. Am Ind logical disease in two mangan
Hyg Assoc $尹$ 1966;27:454-9.

15 Hine $\mathrm{CH}$, Pasi A. Manganese intoxication. West 7 Med 1975;123:101-7.

16 Nelson K, Golnick J, Korn T, Angle C. Manganese encephalpathy: utility of early magnetic resonance imaging. Br F Ind Med 1993;50:510-3.

17 Knight GS, Williams HEM, Hinton D. Elevated plasma manganese levels in welders cutting manganese steel. $N Z$ Med Э 1985;98:870.

18 Ulfvarson U. Survey of air contaminants from welding. Scand $\mathcal{F}$ Work Environ Health 1981;7(suppl 2):28.

19 Sjögren $B$, Lidums V, Håkansson $M$, Hedström $L$. Exposure and urinary excretion of aluminum during welding. Scand $\mathcal{f}$ Work Environ Health 1985;11:39-43.

20 Slanina P, Frech W, Bernhardson Å, Cedergren A Mattsson P. Influence of dietary factors on aluminium absorption and retention in the brain and bone of rats. absorption and retention in the brain

21 Versieck J, Vanballenberghe L, de Kesel A, Hoste J, Wallaeys B, Vandenhaute $\mathrm{J}$, et al. Certification of second-generation biological reference material (freezedried human serum) for trace element determinations. Anal Chim Acta 1988;204:63-75.

22 Kristenson $\mathrm{H}$, Trell E. Indicators of alcohol consumption: comparisons between a questionnaire (Mm-MAST) interviews and serum gamma-glutamyl tranferase (GGT) in a health survey of middle-aged males. British fournal of Addiction 1982;77:297-304.
23 Axelson $\mathrm{O}$, Hogstedt $\mathrm{C}$. The health effects of solvents. In: Zenz C, Dickerson OB, Horvath EP, eds. Occupational Zenz C, Dickerson OB, Horvath EP, eds. Occupational medicine,

24 Hänninen $H$, Matikainen $E$, Kovala $T$, Valkonen $S$, Riihimäki V. Internal load of aluminum and the central nervous system function among aluminum welders. Scand $\mathcal{f}$ Work Environ Health 1994;20:279-85.

25 Gamberale F, Iregren A, Kjellberg A. SPES: the computerized Swedish performance evaluation system. Background, critical issues, and a user's manual. Arbete och Hälsa 1989;6:77

26 Amoore JE, O'Neill RS. Proposal for a unifying scale to express olfactory threshold and odour levels: the decismels scale. Fournal of the Air Pollution Control Association 1988;38:19-24.

27 Golden CJ. Diagnosis and rehabilitation in clinical psychology. Springfield, Illinois: Charles C Thomas, 1981.

28 Sjögren B, Elinder CG. Aluminium. In: Beije B, Lundberg $P$, eds. Criteria documents from the Nordic expert group 1992. Arbete och Hälsa 1993;1:55-84.

29 White DM, Longstreth WT, Rosenstock L, Claypoole KHJ, Brodkin CA, Townes BD. Neurologic syndrome in 25 workers from an aluminum smelting plant. Arch Intern Med 1992;152:1443-8.

30 White DM, Longstreth WT, Rosenstock L, Claypoole KHJ, Brodkin CA, Townes BD. Correction. Arch Intern Med 1993;153:2796.

31 Bast-Pettersen R, Drablos PA, Goffeng LO, Thomassen Y, Torres CG. Neuropsychological deficit among elderly workers in aluminum production. Am $\mathcal{f}$ Ind Med 1994; 25:649-62.

32 Hosovski E, Mastelica Z, Sunderic D, Radulovic D. Mental abilities of workers exposed to aluminium. Med Mental abilities of wor

33 Altmann P, Dhanesha U, Hamon C, Cunningham J, Blair J, Marsh F. Disturbance of cerebral function by aluminium in haemodialysis patients without overt aluminium toxicity. Lancet 1989;ii:7-12.

34 Rifat SL, Eastwood MR, Crapper McLachlan DR, Corey PN. Effect of exposure of miners to aluminium powder. Lancet 1990;ii:1162-5.

35 Mergler D, Huel G, Bowler R, Iregren A, Bélanger S, Baldwin $\mathrm{M}$, et al. Nervous system dysfunction among workers with long-term exposure to manganese. Environ Res 1994;64:151-80.

36 Roels H, Lauwerys R, Buchet J-P, Genet P, Jawad Sarhan $\mathrm{M}$, Hanotiau I, et al. Epidemiological survey among workers exposed to manganese: effects on lung, central Mervous system, and $1987 ; 11: 307-27$.

37 Siegl P, Bergert K-D. Eine früdiagnostische Uberwachungsmethode bei Manganexposition. Zeitschrift für die Gezamte Hygiene und ihre Grenzgebiehe 1982;28: 524-6. (In German.)

38 Roels H, Ghyselen P, Buchet J-P, Ceulemans E, Lauwerys R. Assessment of the permissible exposure level to manganese in workers exposed to manganese dioxide dust. $B r$ f Ind Med 1992;49:25-34.

39 Wennberg A, Iregren I, Struwe G, Cizinsky G, Hagman M, Johansson L. Manganese exposure in steel smelters a Johansson L. Manganese exposure in steel smelters a Environ Health 1991;17:255-62

40 Lucchini R, Selis L, Folli D, Apostoli P, Mutti A, Vanoni $\mathrm{O}$, et al. Neurobehavioral effects of manganese in workers from a ferroalloy plant after temporary cessation of exposure. Scand F Work Environ Health 1995;21:143-9.

41 Iregren A. Using psychological tests for the early detection of neurotoxic effects of low level manganese exposure. Neurotoxicol 1994;15:671-7.

42 Tsuchiya K. Lead. In: Friberg L, Nordberg GF, Vouk VB, eds. Handbook on the toxicology of metals, vol II, 2nd edition. Amsterdam: Elsevier, 1986:298-353.

\section{Correspondence and editorials}

Occupational and Environmental Medicine welcomes correspondence relating to any of the material appearing in the journal. Results from preliminary or small scale studies may also be published in the correspondence column if this seems appropriate. Letters should be not more than 500 words in length and contain a minimum of references. Tables and figures should be kept to an absolute minimum. Letters are accepted on the understanding that they may be subject to editorial revision and shortening.

The journal also publishes editorials which are normally specially commissioned. The Editor welcomes suggestions regarding suitable topics; those wishing to submit an editorial, however, should do so only after discussion with the Editor. 